\title{
The Mapping of Spanish Social Psychology through its Conferences: A Bibliometric Perspective
}

\author{
Lupicinio Íñiguez-Rueda, Luz María Martínez-Martínez, Juan Manuel Muñoz-Justicia, \\ M ${ }^{\mathrm{a}}$ Carmen Peñaranda-Cólera, Miguel Angel Sahagún-Padilla, \& José Gerardo Alvarado \\ Universitat Autònoma de Barcelona
}

\begin{abstract}
This study of papers gathered from the proceedings presented at Spanish social psychology conferences explores the use of bibliometrics for studying scientific disciplines. A reference database of all the papers included in the conference proceedings of events held from 1983 to 2000 was generated and classified by thematic area, paper type and author institutional affiliation. The references were laid out on contingency tables and mapped with correspondence analysis. The results show that there is a growing number of co-authored papers and a predominance of empirical over theoretical paper types. Some institutions have a higher concentration of theoretical papers while others work mostly in the areas of organizational and health psychology. In terms of empirical papers, there is a tendency towards generating more qualitative-based studies over the span of time captured by this work. There are also a number of papers written about such areas as cultural psychology that points to the emergence of an interest in critical social psychology. Concluding remarks underline the role of conferences and scientific meetings as an important indicator of the dynamic development of a scientific discipline.

Keywords: Spanish social psychology; bibliometrics, conference proceedings, subject areas, types of studies
\end{abstract}

\begin{abstract}
Este estudio de trabajos recogidos de las actas presentadas en conferencias de Psicología Social española explora el uso de los bibliométricos para estudiar las disciplinas científicas. Se generó y se clasificó por área temática, tipo de trabajo y afiliación institucional del autor una base de datos de referencia de todos los trabajos incluidos en las actas de las conferencias de eventos celebradas desde 1983 hasta 2000 . Se ordenaron las referencias en tablas de contingencia correlacionadas con análisis de correspondencia. Los resultados muestran que el número de trabajos con co-autores incrementa y hay predominancia de trabajos de tipo empírico sobre teórico. Algunas instituciones tienen mayor concentración de trabajos teóricos, mientras que otras trabajan más en las áreas de la psicología organizacional y de la salud. En términos de trabajos empíricos, hay una tendencia hacia la generación de estudios con más base cualitativa en el intervalo temporal captado por este trabajo. También hay un número de trabajos escritos sobre áreas tales como la psicología cultural, lo que indica la emergencia de un interés en la psicología social crítica. Los comentarios finales subrayan el papel de las conferencias y encuentros científicos como un indicador importante del desarrollo dinámico de una disciplina científica.

Palabras clave: psicología Social española, bibliométricos, actas de conferencias, áreas temáticas, tipos de estudios
\end{abstract}

The authors wish to thank to all the people who participated in the classification of conference papers and in the construction of the database on which this study is based. They also want to thank to the reviewers of the article for their critical and, at the same time, constructive observations, which were extraordinarily useful

Correspondence concerning this article should be addressed to Lupicinio Iñiguez Rueda, Departament de Psicologia Social, Universitat Autònoma de Barcelona, Edifici B, 08193 Bellaterra (Cerdanyola del Vallès), Barcelona, Spain. E-mail: Lupicinio.Iniguez@uab.cat 
Amalio Blanco and Luis de la Corte (2001) published an article in this same journal detailing the theoretical and research production of Spanish Social Psychology for the decade from 1989 to 1998, based on information gathered from databases such as MEDLINE, PsycLIT, ERIC and PSICODOC98 as well as on papers presented at five Spanish social psychology conferences. The authors point out that the fundamental areas of investigation were: a) work and organizational psychology; b) social psychology of health; c) social service and community psychology; d) environmental psychology; e) legal and political psychology; f) psychosocial theory and meta-theory; g) social psychology of language; h) emotion research; and i) the area of group processes and social identity. They conclude that the growing importance of social psychology within Spanish psychology is closely linked to the context of Spanish social problems while also insisting that the relative scarcity of theoretical originality in Spanish psychology is due to a strong AngloSaxon influence in the discipline ${ }^{1}$.

This article describes a somewhat similar study with relevant differences regarding its data and method: a) it is exclusively based on the conference proceeding papers of eight social psychology conferences or meetings held in Spain from 1983 to 2000; b) a descriptive analysis is carried out by means of bibliometric procedures; c) conference papers have been classified according to their thematic area, paper type and author institutional affiliation; and d) a correspondence analysis is done to determine relationships between all of the aforementioned categories.

\section{A Bibliometric Approach}

Bibliometrics can be defined as the application of statistical and mathematical methods to analyze written communication processes and the nature and development of scientific disciplines through counting techniques and the analysis of texts (Alan Pritchard, 1969). In general terms, Bibliometrics consists of a set of techniques and procedures that quantify scientific literature for analysis (Ikpaahindi, 1985). Traditionally, these procedures have largely been used to quantify the productivity of authors, professional journals and academic disciplines. Nevertheless, they also seem to be helpful as a way to look at the processes and nature of science, understood as far back as 1960 in terms of scientometrics or the science of science (Callon, Courtial \& Penan, 1993; Leydesdorff, 2001). This broader scope allows us to quantify the results of a given discipline in order to look at its activity, structure and evolution. Scientometrics can be applied in fields such as biblioteconomy, history of science, sociology of science or science-related policies. Examples of thematic areas in which bibliometrics has had an important role are: a) the study of collaborative patterns across countries or disciplines; b) bibliometric indicators in international academic rankings for universities; c) the process of publishing (targeting journals, time lags, gatekeepers); d) the use of bibliometric indicators in policy-making and e) the effects of the impact factor and similar measures in publishing activities.

Bibliometrics is not a homogeneous orientation. It can be broken down into descriptive and evaluative areas. Purely quantitative aspects such as productivity or geographical, documental and thematic distribution are at the core of the first area. Based on descriptive results, the second area consists of applying specific criteria to assess scientific activity.

The use of indicators, which itself requires the development of databases and document digitalization is the basis for bibliometric research. Some of the principal scientific literature indicators are: a) publication productivity of periodicals (e.g., journals and series), of single publications (e.g., books and monographs) and of "gray literature" (e.g. unpublished papers, theses, conference proceedings, and reports); b) author productivity, generally measured by the number of publications published by an investigator, a group of investigators, an institution, or a country over a specific period of time; c) publisher productivity, including publisher location, which identifies "circuits" through which a discipline moves; d) quotations analysis and impact indexes, including their relation to "invisible colleges"; and e) productivity by subject area.

The production activity of each discipline has its own characteristics and preferred kinds of publications. Monographs and compilations in the human and social sciences make up $50 \%$ to $80 \%$ of the publication activity while in the case of the natural sciences $80 \%$ of its publications consist of articles in professional journals (Rubio, 1998). For technology-centered disciplines conference literature is the most important (Moed \& Visser, 2007). Moreover, every discipline has its own publication guidelines. Scientific papers in the natural sciences often result from the work of large research teams and are usually co-authored. In the human and social science disciplines, many of which split up into more specific knowledge areas, publications are more often written by single authors. The types of documents are also more diverse, they can be

\footnotetext{
1 Spanish social psychology suffered the same effects of the civil war shared by the rest of the other sciences; a prolonged intellectually orphaned period. It was not until the 1960's that research areas such as attitudes, group behavior and mass media started to be taken into account, a period characterized by relative isolation from the scientific activity in the rest of Europe. In the 1980's the situation changed and the new encounters sparked the initiation of some of the first collaborative networks.
} 
monographs, articles, essays, and papers included in scientific conference proceedings. The object of study in bibliometrics then consists of theoretical or empirical productions published in a variety of formats. The subsequent analysis of the data can trace publication activity and evaluate the dimensions of research activity of a particular discipline.

All of the scientific disciplines have drawn the interest of bibliometrics (Borgman, 1990; Borgman \& Furner, 2002) and psychology has not been an exception. At its root this study relies on bibliometric work pioneered in the 1970s (Lascurain, López López and González Uceda, 1997) and published around the 1980s. As shown below, Spanish bibliometric research in the field of psychology varies in scope, aims and procedures. An example of some early work that focuses on the history of the discipline can be found in Carpintero (1980) and Tortosa (1989) while the earlier work of Carpintero, Peiró and Quintanilla, (1977) was one of the first attempts to offer a view of the discipline by analyzing articles published from 1969 to 1974 in the journal Anuario de Psicología. Carpintero and Peiró (1978) later offered a method based on the content analysis of article abstracts which can be seen as an antecedent for our study. It aimed to establish build a network based on the data to offer a view of the state of research in a specific field by determining investigation areas, categories and concepts. Additionally, there were other attempts to demonstrate how bibliometrics could provide an orientating representation of a scientific field situation for a given time period, such as to see who is writing about behavior modification (Carpintero \& Peiró, 1980). These authors edited a book (Carpintero \& Peiró, 1981) in which the different ways of applying bibliometrics to the study of psychology were detailed.

The analysis of articles published in the Revista de Psicología General y Aplicada from 1946 to 1970 done by Pastor-Carballo and Carpintero (1980) identified the most productive authors and the degree to which they collaborated, and also pointed out that there was a greater number of papers covering subjects related to methodology and industrial psychology. Similarly, Miralles (1980) conducted a bibliometric study of Spanish psychology analyzing articles published in journals such as the Revista de Psicología General y Aplicada, the Anuario de Psicología, the Análisis y Modificación de Conducta, and the Cuadernos de Psicología. At the same time, there was pioneering work in the identification of 'invisible colleges' through the analysis of co-authored articles in some U. S. journals (Peiró, 1980).

Bibliometrics was also used in the analysis of handbooks (Tortosa \& Carpintero, 1980) and Ibáñez (1990) focused on social psychology. Calatayud, Carpintero, Peiró, and Tortosa (1985) show early bibliometric research was not only concerned with the study of recent Spanish psychology. They identify the main groups American psychologists writing prior to World War II through a review of co- authorships in articles published in Psychological Review. In a different direction, Pérez Alonso-Geta (1985) conducted a bibliometric study to measure the presence of psychology in Spanish pedagogy conferences. Carpintero (1980), in a broader sense, highlights the role of bibliometrics in producing images of scientific work in psychology. In doing so, he is able to distinguish between science as bodies of knowledge, as a social institution, and as something scientists do.There have recently been a growing number of studies dealing with specific bibliometric indicators such as: a) the thematic analysis of materials published in specialized journals, conference proceedings, dissertations, and financed research projects (e.g., Gallardo, 1996); b) the productivity of Spanish psychology through the analysis of dissertations by institution and mentor (e.g., Agudelo et al., 2003); and c) the study of themes, networks, co-authorship, and author productivity in specific journals (e.g., Peñaranda, Quiñones, \& López García, 2005).

In line with the growing interest in bibliometrics as an appropriate approach for a deeper understanding of current Spanish social psychology, this paper focuses on scientific production according to its thematic areas. This kind of approach captures some of the most interesting and complex aspects of the life of a scientific discipline because it can identify and describe research interest trends and the theoretical-methodological positions on which studies are based.

The most common procedure consists of a thematic analysis of key words found in titles and text, as well as descriptors, summaries or classifications. Different aspects of thematic areas are employed in the analysis of the data: (a) number of published works by theme, (b) chronological distribution of themes in a discipline or area, (c) absence or abundance of themes, (d) trends and modes of activity based on the appearance and disappearance of themes, and (e) the thematic overlap among disciplines.

The materials analyzed in this study are the papers presented in conference proceedings in response to the scarce attention given to scientific meetings. Considering the abundance of publication centered studies - most of them on specialized journals -, there is a relative lack of research about one of the key features of scientific activity, one that consists of spaces in which encounters, knowledge circulation and relationships are fostered. This lack of attention, due in part to the absence of a proceedings index that is organized and accessible is what this study is intended to address. Conceived as a first step in a wider and ongoing group of studies, this paper offers a general account of social psychology conferences in Spain, thus providing a foundation for addressing more specific questions.

\section{Database Building and Analytic Tools}

A reference database of conference papers included in 8 Spanish social psychology conference proceedings was 
constructed $^{2}$. The reference database was set up by author, author's gender, author's institutional affiliation, paper type, paper thematic area, and also included all of the references cited in the paper. The construction process roughly consisted of six phases: (a) entering the complete reference of each paper as well as the references cited in the paper into a reference management application (Biblioscape), (b) exporting the references to a database application (Access), and (c) adding the institutional affiliation for each conference paper into the database file. At this point we decided to (d) add the gender of each of the authors if it was available and then proceeded to (e) identify each conference paper by type and (f) thematic area ${ }^{3}$.

The database itself deserves special mention since it fills an important void. It offers the possibility of including new data as more Spanish social psychology conferences take place. Besides this feature, in as much as the design of the database allows users to find or establish cross-references among entries, it also allows for the application of different analytical approaches to the data and for conducting more specific studies.

In addition to the foreseeable difficulties encountered when a large volume of information is handled, other important problems related to the "quality" of the data were noticed. A significant bulk of errors resulted due to missing information, attributed in part to typographical errors in some of the sources. The database was purged of errors in two phases, first by the automatic elimination of duplicates and then by conducting an exhaustive examination of every conference proceeding paper and the references cited in each.

The research team was then able to continue on to the analysis of the data which was also done in two phases. First, a social network analysis application (Unicet 6, Borgatti, Everett, \& Freeman, 2002) was used to produce a descriptive analysis based mostly on contingency tables. Next, a correspondence analysis of paper characteristics was carried out. Correspondence analysis responds to the need to delve deeply into dependency relationships established between two observed categorical variables in a single population, thus being helpful for explanatory purposes. Correspondence Analysis techniques allow finding out how the different values or categories of both variables are related to each other (García Santesmases, 1984).

The total number of references in the database is 21,403 . Of these, 1,625 of the references are the conference proceeding papers while the remaining 19,778 are the references cited in each paper. This particular study only looks at the first group and analyzes them in terms of: a) conference proceeding source, b) author(s') institutional affiliation, c) type of paper, and d) the paper's thematic area. The same corpus of data, references cited in each paper included, has also been analyzed elsewhere following a Social Networks Analysis approach. Some results of this work are reported in Íñiguez, Muñoz, Peñaranda, and Martínez (2006) ${ }^{4}$.

\section{General Description}

The corpus for the analysis is the set of Spanish social psychology meetings and conferences held from 1983 to 2000 (see Table 1). The combined meetings and conferences consists of 1,625 papers written by a total of 2,389 authors. Many of the authors wrote more than one paper and when we corrected for this duplication the total number of different

Table 1

Authors and Papers by Conference

\begin{tabular}{|c|c|c|c|c|c|c|}
\hline Conference & Location & Year & Authors & $\%$ & Papers & $\%$ \\
\hline III Jornadas de Psicología Social & Las Palmas & 1983 & 38 & 1.59 & 27 & 1.66 \\
\hline I Congreso de Psicología Social & Granada & 1984 & 156 & 6.53 & 113 & 6.95 \\
\hline II Congreso de Psicología Social & Alicante & 1988 & 259 & 10.84 & 190 & 11.69 \\
\hline III Congreso de Psicología Social & Santiago & 1990 & 266 & 11.13 & 183 & 11.26 \\
\hline IV Congreso de Psicología Social & Sevilla & 1992 & 412 & 17.25 & 327 & 20.12 \\
\hline V Congreso de Psicología Socia & Salamanca & 1994 & 389 & 16.28 & 246 & 15.14 \\
\hline VI Congreso de Psicología Social & Donosti & 1996 & 312 & 13.06 & 193 & 11.88 \\
\hline VII Congreso de Psicología Social & Oviedo & 2000 & 557 & 23.32 & 346 & 21.29 \\
\hline Total & & & 2,389 & 100.00 & 1,625 & 100.00 \\
\hline
\end{tabular}

2 The database was built by José Gerardo Alvarado, Ma Esther Castillo, Ana Isabel Garay, Francisco Jeanneret, Luz María Martínez, María Carmen Peñaranda, M José Reyes, Miguel Ángel Sahagún and María Mar Velasco, with the collaboration of Rafael Barrera, Noel García, Pamela Gutiérrez, Nelson Molina, Joaquín Navajas, Viviana Pacheco, Eduardo Rodríguez and Nicole Schmall.

3 The classification of papers by type and thematic area was carried out by Joel Feliu, Ana Garay, Luz M Martínez and Anna Vitores.

4 In this study, Social Networks Analysis and Bibliometrics are applied in order to explore the structure of scientific production and communication in Spanish social psychology. Such an approach allows us to identify communities, their research interests and dynamics, directing us to a better understanding of the role 'invisible colleges' play in the life of the discipline. 
Table 2

Percentage of the Number of Authors per Paper by Conference

\begin{tabular}{lrrrrrrrrr}
\hline $\begin{array}{l}\text { Number of authors } \\
\text { per paper } \backslash \text { Conferences }\end{array}$ & Las Palmas & Granada & Alicante & Santiago & Sevilla & Salamanca & Donosti & Oviedo & Total \\
\hline 1 & & & & & & & & & \\
2 & 74.07 & 47.79 & 35.79 & 38.80 & 29.66 & 33.74 & 39.38 & 30.35 & $35.32(574)$ \\
3 & 14.81 & 26.55 & 24.21 & 22.40 & 30.28 & 31.30 & 27.46 & 27.75 & $27.45(446)$ \\
4 & 3.70 & 17.70 & 25.26 & 17.49 & 21.71 & 22.36 & 17.10 & 23.12 & $20.92(340)$ \\
5 & 0.00 & 1.77 & 11.05 & 10.38 & 9.48 & 8.94 & 8.81 & 8.67 & $8.74(142)$ \\
6 & 3.70 & 3.54 & 2.63 & 6.56 & 6.12 & 1.63 & 3.11 & 5.20 & $4.31(70)$ \\
7 & 3.70 & 1.77 & 0.53 & 2.73 & 2.45 & 1.63 & 2.07 & 1.45 & $1.85(30)$ \\
8 & 0.00 & 0.88 & 0.00 & 1.64 & 0.00 & 0.41 & 1.04 & 2.02 & $0.86(14)$ \\
9 & 0.00 & 0.00 & 0.00 & 0.00 & 0.31 & 0.00 & 1.04 & 0.87 & $0.37(6)$ \\
10 & 0.00 & 0.00 & 0.00 & 0.00 & 0.00 & 0.00 & 0.00 & 0.00 & $0.00(0)$ \\
11 & 0.00 & 0.00 & 0.53 & 0.00 & 0.00 & 0.00 & 0.00 & 0.00 & $0.06(1)$ \\
12 & 0.00 & 0.00 & 0.00 & 0.00 & 0.00 & 0.00 & 0.00 & 0.29 & $0.06(1)$ \\
13 & 0.00 & 0.00 & 0.00 & 0.00 & 0.00 & 0.00 & 0.00 & 0.00 & $0.00(0)$ \\
Total & 0.00 & 0.00 & 0.00 & 0.00 & 0.00 & 0.00 & 0.00 & 0.29 & $0.06(1)$ \\
& 100.00 & 100.00 & 100.00 & 100.00 & 100.00 & 100.00 & 100.00 & 100.00 & 100.00 \\
\hline
\end{tabular}

authors came out to 1,499. Of these, 601 are women, 592 are men and the rest were not identifiable by gender. Table 1 shows the location and year of each of each of the conferences along with the number of authors and papers included in the corresponding conference proceedings.

In terms of the number of conference papers per author, those who wrote or participated in the co-authorship of more than 15 papers only represent $1.5 \%$ (23) of the total number of different authors. In fact, about 56\% (849) of the authors only wrote or participated in the co-authorship of one paper. Table 2 shows that $35.32 \%$ of the papers were signed by one author and that a larger part of them were co-authored (64.68\%). The table also shows that the percentage of papers presented by a sole author has considerably decreased from $74.07 \%$ to $30.35 \%$ over the span of time captured by this study.

About the number of authors by paper $(M=2.31, S D=$ 1.41), $89.73 \%$ of the different authors have co-authored papers while the percentage of authors having written a paper alone is $10.27 \%$. Table 3 shows that the number of authors per coauthored paper is between 1 and 5 in $68.25 \%$ of the cases.

Table 3

Number of Authors per Co-authors

\begin{tabular}{lrr}
\hline Co-authors & $N$ & $\%$ \\
\hline None & 154 & 10.27 \\
1 to 5 co-authors & 1,023 & 68.25 \\
6 to 10 co-authors & 241 & 16.08 \\
11 to 15 co-authors & 54 & 3.60 \\
16 to 20 co-authors & 13 & 0.87 \\
21 to 25 co-authors & 8 & 0.53 \\
26 or more co-authors & 6 & 0.40 \\
Total & 1,499 & 100.00 \\
\hline
\end{tabular}

\section{Institutional Affiliation}

Authors from 44 Spanish universities are included in the 8 different conference proceedings in addition to various authors from other institutions, centers, and professional organizations, some of which are located in other countries. There are 7 universities with more than 100 authors included in the conference proceedings and among those the Universidad de Valencia (173) and the Universidad Autónoma de Barcelona (130) account for the highest numbers. Table 4 shows that the percentage of papers included in the conference proceedings by 13 highly represented institutions slowly declined across the period captured by this study. The 13 universities with the most papers in the Granada conference proceedings $(87.81 \%)$ make up a smaller part of the papers in the Oviedo proceedings $(54.75 \%)$.

\section{Thematic Analysis}

As mentioned above, a conference proceeding paper classification has been done by identifying the papers by type and grouping them by thematic area.

Paper types. There are 3 basic paper types: a) those that are theoretical; b) those that are quantitative empirical; and c) those that are qualitative empirical papers. Each conference paper has also been identified by a number of sub-types that have their own definitions (Appendix A, Table 1). Table 5 shows the distribution by paper type. When compared to the theoretical type of paper $(31.02 \%)$, the major bulk of the social psychology conference papers were empirical, of which $58.03 \%$ are qualitative and $10.95 \%$ are quantitative. 
Table 4

Percentage of Papers by Institutional Affiliation and Conference

\begin{tabular}{|c|c|c|c|c|c|c|c|c|}
\hline Institutional affiliation $\backslash$ Conference & Las Palmas & Granada & Alicante & Santiago & Sevilla & Salamanca & Donosti & Oviedo \\
\hline Universidad Autónoma de Barcelona & 15.79 & 7.05 & 11.97 & 10.15 & 8.74 & 7.97 & 5.45 & 5.92 \\
\hline Universidad Autónoma de Madrid & 13.16 & 5.13 & 3.09 & 4.89 & 1.94 & 3.08 & 5.13 & 4.67 \\
\hline Universidad Complutense & 18.42 & 9.62 & 6.95 & 7.52 & 4.85 & 3.86 & 6.09 & 4.67 \\
\hline Universidad de Alicante & 0.00 & 8.33 & 2.32 & 2.26 & 1.70 & 2.57 & 0.00 & 0.18 \\
\hline Universidad de Barcelona & 18.42 & 8.33 & 6.18 & 4.89 & 4.37 & 7.97 & 10.58 & 4.85 \\
\hline Universidad de Granada & 5.26 & 12.82 & 4.63 & 5.64 & 5.34 & 5.14 & 4.17 & 4.31 \\
\hline Universidad de La Laguna & 5.26 & 7.69 & 4.25 & 6.39 & 6.55 & 2.57 & 0.32 & 1.97 \\
\hline Universidad de Málaga & 0.00 & 0.00 & 1.54 & 0.00 & 9.22 & 5.14 & 3.21 & 2.69 \\
\hline Universidad de Oviedo & 0.00 & 0.00 & 0.39 & 1.13 & 4.37 & 2.31 & 1.92 & 6.82 \\
\hline Universidad de Santiago & 0.00 & 8.33 & 5.02 & 7.14 & 1.70 & 4.11 & 3.53 & 2.87 \\
\hline Universidad de Sevilla & 0.00 & 8.33 & 7.72 & 9.40 & 8.01 & 7.46 & 4.17 & 4.85 \\
\hline Universidad de Valencia & 0.00 & 7.05 & 23.17 & 20.68 & 16.02 & 14.65 & 6.73 & 6.46 \\
\hline Universidad del País Vasco & 0.00 & 5.13 & 6.95 & 4.51 & 5.34 & 6.17 & 13.14 & 4.49 \\
\hline Total & $\begin{array}{r}76.31 \\
(21)\end{array}$ & $\begin{array}{r}87.81 \\
(99)\end{array}$ & $\begin{array}{l}84.18 \\
(160)\end{array}$ & $\begin{array}{l}84.60 \\
(155)\end{array}$ & $\begin{array}{l}78.15 \\
(156)\end{array}$ & $\begin{array}{l}73.00 \\
(180)\end{array}$ & $\begin{array}{l}64.44 \\
(124)\end{array}$ & $\begin{array}{l}54.75 \\
(189)\end{array}$ \\
\hline
\end{tabular}

Note: Only those institutions with a higher numbers of papers are included in the table.

In general terms, the distribution of papers by type does not vary significantly from conference to conference with the exception of the Canarias conference where there were a greater number of theoretical papers (see Table 6). By eliminating the small number of papers presented at the Canarias conference $(27$ of 1,625$)$ we can see that the number of theoretical papers has stayed close to $30 \%$ throughout the period captured in this study despite a small surge that shows up in the most recent conference. In the case of the quantitative empirical papers that make up the bulk of the database, we can also see that the number of papers of this type stays close to $60 \%$ despite the appreciably lower rates at the most recent conference (49\%). In terms of the percentage of qualitative empirical papers, there is a sharp rise throughout the period captured in this study, going from $5.31 \%$ at the Granada conference to $13.87 \%$ at the Oviedo conference. This undoubtedly reflects the growing trend in the use of qualitative methods in all of the social sciences.

Table 5

Papers by Type

\begin{tabular}{|c|c|c|}
\hline Type & Papers & $\%$ \\
\hline Epistemological & 31 & 1.91 \\
\hline Theoretical & 261 & 16.06 \\
\hline Theoretical-Methodological & 70 & 4.31 \\
\hline Essay & 108 & 6.65 \\
\hline Theoretical (other) & 34 & 2.09 \\
\hline Total (Theoretical) & 504 & 31.02 \\
\hline Experimental quantitative & 144 & 8.86 \\
\hline Correlational quantitative & 741 & 45.60 \\
\hline Quantitative (other) & 58 & 3.57 \\
\hline Total (Quantitative empirical) & 943 & 58.03 \\
\hline Interactionist hermeneutic qualitative & 62 & 3.82 \\
\hline Linguistic qualitative & 26 & 1.60 \\
\hline Ethnographic qualitative & 10 & 0.62 \\
\hline Action-Research qualitative & 40 & 2.46 \\
\hline Qualitative (other) & 40 & 2.46 \\
\hline Total (Qualitative empirical) & 178 & 10.95 \\
\hline Total & 1,625 & 100.00 \\
\hline
\end{tabular}


Table 6

Percentage of Papers by Type and Conference

\begin{tabular}{lrrrrrrrrr}
\hline Type \Conference & Las Palmas & Granada & Alicante & Santiago & Sevilla & Salamanca & Donosti & Oviedo & Total \\
\hline Theoretical & 59.26 & 33.63 & 27.89 & 32.79 & 29.05 & 23.17 & 30.05 & 36.71 & $31.02(504)$ \\
Quantitative empirical & 33.33 & 61.06 & 64.21 & 60.11 & 59.33 & 63.01 & 58.55 & 49.42 & $58.03(943)$ \\
Qualitative empirical & 7.41 & 5.31 & 7.89 & 7.10 & 11.62 & 13.82 & 11.40 & 13.87 & $10.95(178)$ \\
Total & 100.00 & 100.00 & 100.00 & 100.00 & 100.00 & 100.00 & 100.00 & 100.00 & 100.00 \\
& $(27)$ & $(113)$ & $(190)$ & $(183)$ & $(327)$ & $(246)$ & $(193)$ & $(346)$ & $(1,625)$ \\
\hline
\end{tabular}

Thematic areas. In order to group papers according to thematic areas, a slightly modified version of the taxonomy developed by Amalio Blanco and Luis de la Corte (2001) has been used. Modifications consisted mainly in the addition of some new thematic areas. The whole list utilized in this study, including a brief definition of each topic, can be found in Appendix A, Table 2.

The results of the grouping by area show that most of the conference papers are related to the area of applied research, as opposed to being in the commonly called "basic" research area. According to the results, the thematic area with the greatest number of papers is work and organizational psychology (16.74\%), followed by applied social psychology
- other specific areas (13.29\%), and then by the social psychology of health $(10.22 \%)$. To a much smaller degree but within at a relevant rate of papers included are: a) educational social psychology $(5.60 \%)$, b) theory and method in social psychology $(5.48 \%)$, c) community psychology $(5.35 \%), d)$ political psychology $(5.35 \%)$, and e) the area of environmental psychology $(4.00 \%)$.

There are some trends, however, that deserve to be highlighted as some thematic areas rise and others decline as we look at their distribution over the span of time captured in this study. Among those areas that have declined: a) health psychology has gone from $19.47 \%$ in the Granada conference to $6.07 \%$ in the Oviedo conference proceedings;

Table 7

Percentage of Papers by Type and Thematic Area

\begin{tabular}{|c|c|c|c|c|}
\hline Thematic Area \Type & Theoretical & Quantitative empirical & Qualitative empirical & Total \\
\hline Work and organizational psychology & 25.74 & 64.34 & 9.93 & $100.00(272)$ \\
\hline Applied social psychology - other specific areas & 26.39 & 65.28 & 8.33 & $100.00(216)$ \\
\hline Social psychology of health & 24.10 & 69.88 & 6.02 & $100.00(166)$ \\
\hline Social psychology of education & 36.26 & 51.65 & 12.09 & $100.00(91)$ \\
\hline Theory and method in social psychology & 88.76 & 3.37 & 7.87 & $100.00(89)$ \\
\hline Community psychology & 39.08 & 33.33 & 27.59 & $100.00(87)$ \\
\hline Political psychology & 39.73 & 43.84 & 16.44 & $100.00(73)$ \\
\hline Environmental psychology & 24.62 & 66.15 & 9.23 & $100.00(65)$ \\
\hline Collective and group processes & 36.07 & 49.18 & 14.75 & $100.00(61)$ \\
\hline Legal psychology & 25.00 & 65.00 & 10.00 & $100.00(60)$ \\
\hline Gender processes & 20.83 & 54.17 & 25.00 & $100.00(48)$ \\
\hline Stereotypes, prejudice and discrimination & 22.73 & 70.45 & 6.82 & $100.00(44)$ \\
\hline Identity & 25.00 & 70.00 & 5.00 & $100.00(40)$ \\
\hline Social psychology of language & 20.51 & 74.36 & 5.13 & $100.00(39)$ \\
\hline Cognitive processes and social thought & 18.42 & 73.68 & 7.89 & $100.00(38)$ \\
\hline Attitudes, beliefs and values & 18.42 & 78.95 & 2.63 & $100.00(38)$ \\
\hline Cultural psychology & 29.03 & 67.74 & 3.23 & $100.00(31)$ \\
\hline Social studies of science and technology & 50.00 & 20.00 & 30.00 & $100.00(30)$ \\
\hline Emotion & 31.03 & 62.07 & 6.90 & $100.00(29)$ \\
\hline Social psychology of communication & 31.03 & 55.17 & 13.79 & $100.00(29)$ \\
\hline Emotional bonds and pro-social and anti-social behavior & 14.29 & 67.86 & 17.86 & $100.00(28)$ \\
\hline Social influence processes & 9.52 & 85.71 & 4.76 & $100.00(21)$ \\
\hline Others & 29.41 & 52.94 & 17.65 & $100.00(17)$ \\
\hline History of social psychology & 50.00 & 50.00 & 0.00 & $100.00(8)$ \\
\hline Other basic psychosocial processes & 0.00 & 100.00 & 0.00 & $100.00(5)$ \\
\hline
\end{tabular}


b) the social psychology of education has gone from $13.28 \%$ in Granada to $4.92 \%$ in Oviedo; and c) political psychology has gone from $11.51 \%$ of the papers in Granada to $1.16 \%$ in the Oviedo conference proceedings.

Among those that present increased representation over the span of time that has been studied, the area of work and organizational psychology has gone from $13.28 \%$ in Granada to $21.68 \%$ of the papers in the Oviedo conference proceedings. There has also been an increase in the case of applied social psychology - other areas, with papers representing $7.08 \%$ in Granada compared to $15.03 \%$ in Oviedo. By the same token, the study of gender processes has increased its percentage of papers, going from $3.71 \%$ to $4.34 \%$ across the span of time between the same two conferences.

We can also see a more recent trend of emerging thematic areas. This is the case for cultural psychology and the social studies of science and technology. In the first case, there were no papers in the area of cultural psychology at the Granada conference but after a small presence in the Santiago proceedings, the area gained a foothold in Oviedo (4.05\%). The same thing happened in the case of the social studies of science and technology, an area that did not appear at all in Alicante but that ended up with $4.63 \%$ of the papers in the Oviedo conference proceedings. We think this trend is an interesting response to a growing critical movement in the social sciences and that the two areas may be related to the growth of the movement in Spanish social psychology.

Thematic areas and paper types. By crossing thematic area and paper type (see Table 7) we can clearly see how most of the thematic areas consist of correlational quantitative papers. This trend is markedly significant in the thematic areas of affectional bonds, attitudes, cultural psychology, identity, health, work and organizational psychology, applied social psychology, gender, and education studies (over $50 \%$ of the papers are in these thematic areas). However, basic experimental quantitative type papers are limited to the areas of cognitive and influence processes.

Those areas that represent a higher percentage of theoretical papers are, on the one hand theory and method (as would be expected) and on the other hand the social studies of science and technology area, followed but a strong showing by some papers in the political psychology area. A special note with regards to community psychology is that although it has shown a predominant trend towards having more theoretical papers $(39.08 \%)$, followed by empirical quantitative (33.33\%) and qualitative (27.59\%) papers, the differences in representation of the types of papers does not appear to be as marked as in the other areas.

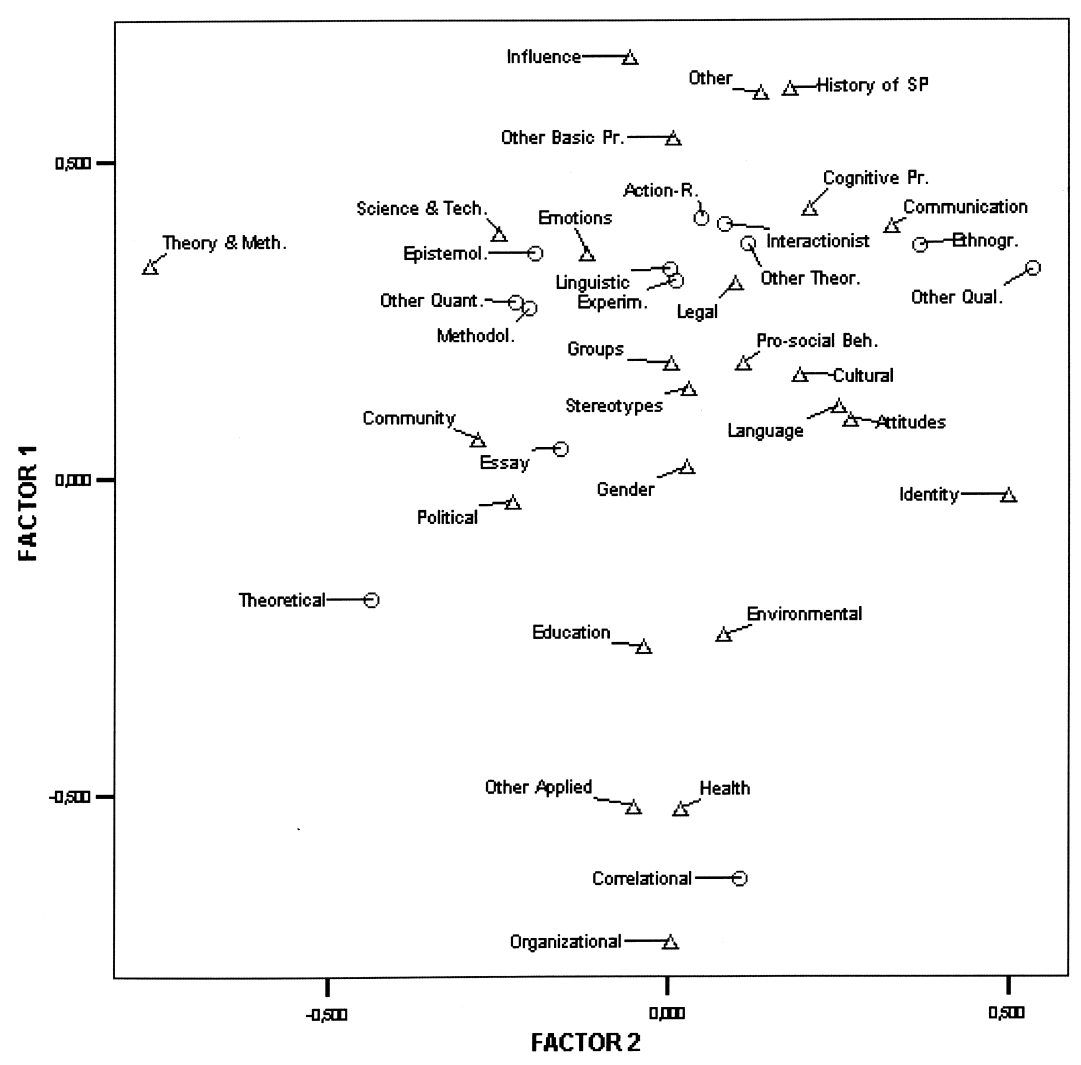

Figure 1. Correspondence analysis: Thematic area by paper type, factors 1 and 2 . 


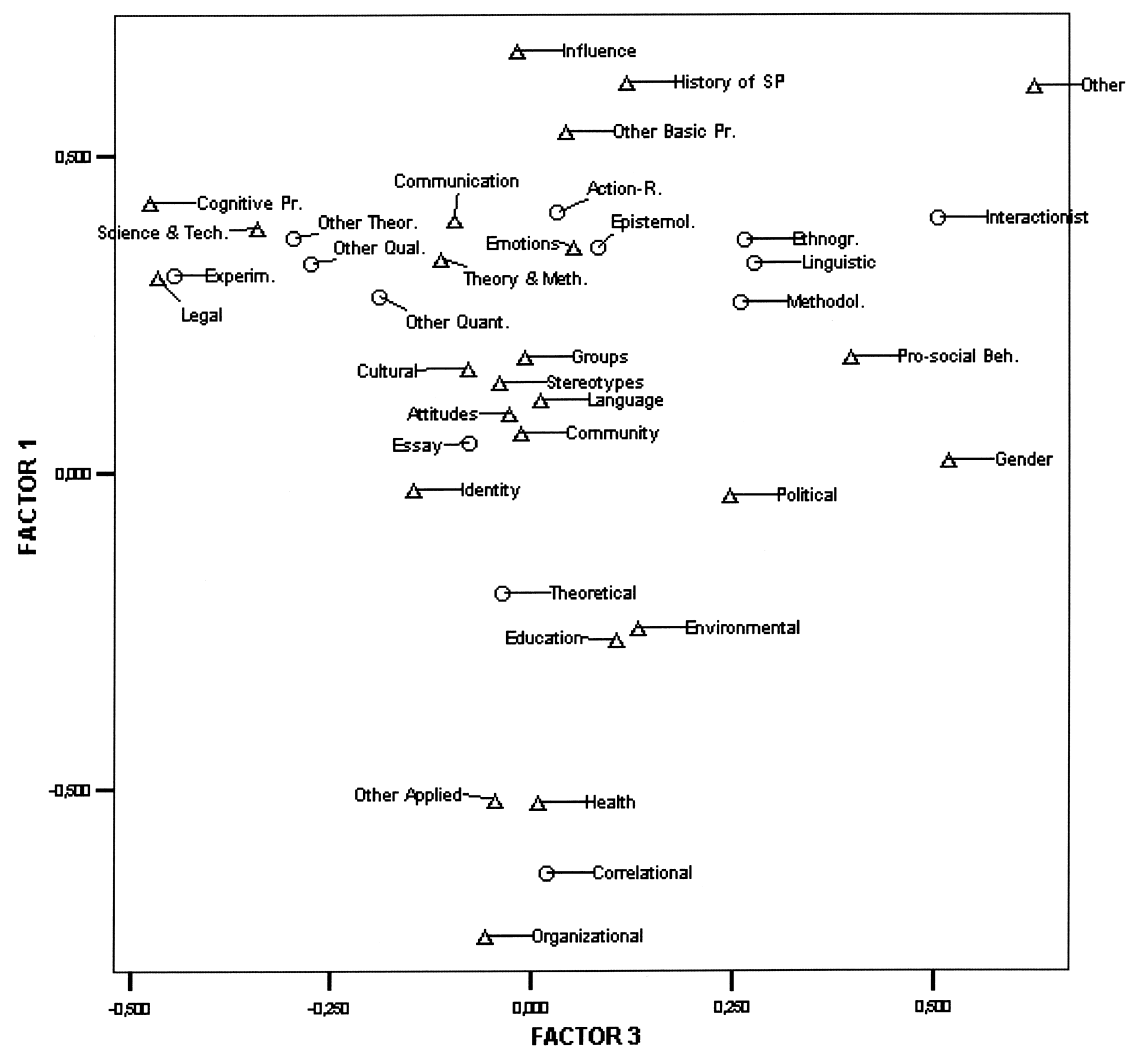

DIMENSIONS

O Paper Type

$\triangle$ Thematic Area

FACTOR 3

Figure 2. Correspondence analysis: Thematic area by paper type, factors 1 and 3 .

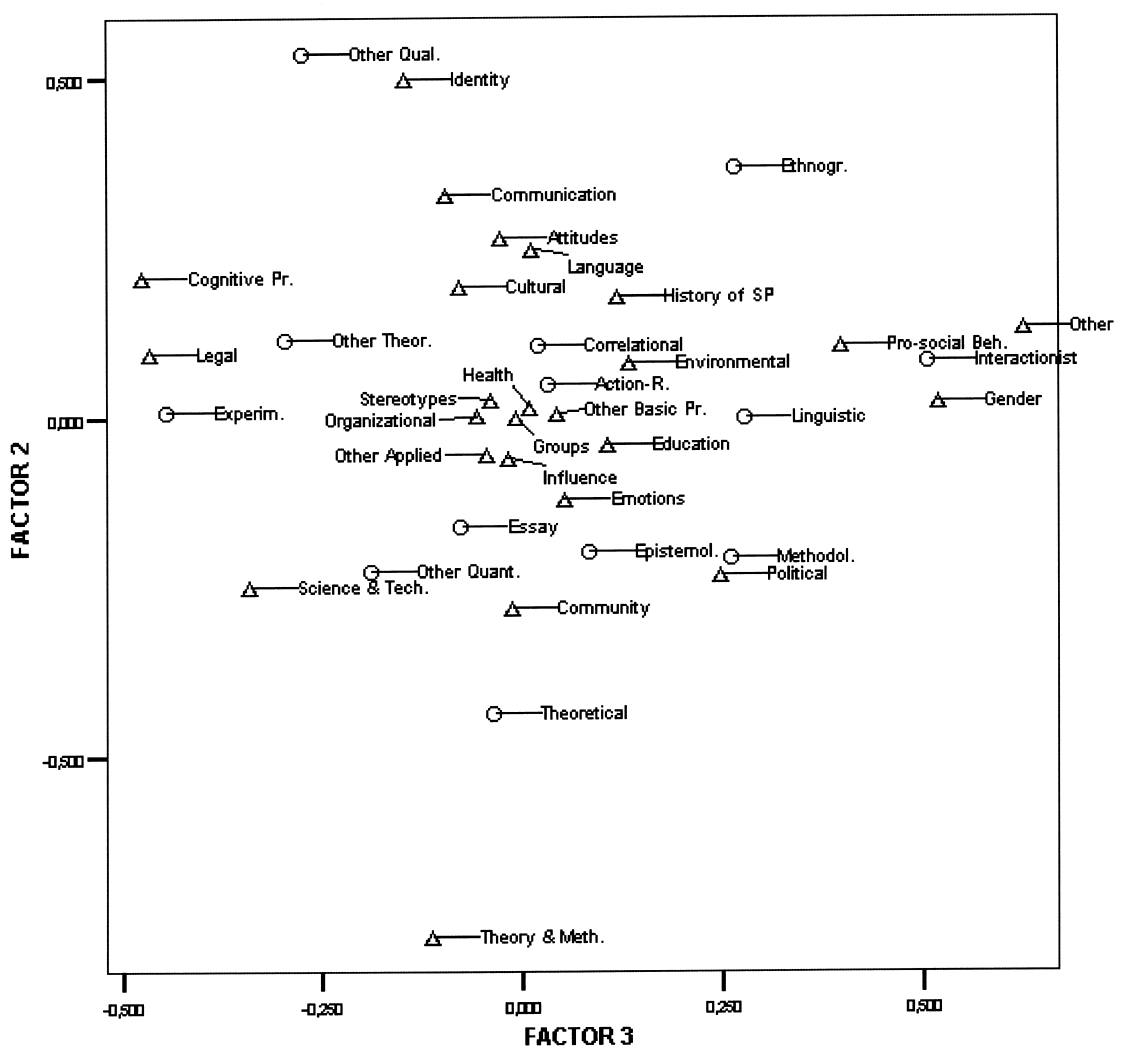

DIMENSIONS

O Paper Type

$\Delta$ Thematic Area

Figure 3. Correspondence analysis: Thematic area by paper type, factors 2 and 3 . 


\section{Correspondence Analysis}

Correspondence analysis results are intended to explore the relationship between paper type, thematic area and institutional affiliation. The analysis proceeds by taking each of the relationships separately: a) between thematic area and paper type; b) between institutional affiliation and paper type; and finally, c) the relationship between thematic area and institutional affiliation.

Thematic area by paper type. In order to account for the relationships between paper type and thematic area, a contingency table was first set up and then subjected to correspondence analysis. Results are shown in the form of a correspondence distribution. The factors and the coordinates of the analysis appear in Table 1 and Table 2 of Appendix $\mathrm{B}$, respectively.

The first axis on Figure 1 (see also Figure 2 and Figure 3) shows a polarity between the basic processes thematic area and the experimental quantitative paper type on one hand, and between the applied process thematic area and the correlational quantitative paper type on the other. The second axis separates the theoretical paper type from the empirical paper type. The third axis shows a polarity between the qualitative and quantitative paper types. The thematic area and paper type coordinate graph shows a distribution, producing a map with particular zones that are associated on the one hand with the health psychology, the work and organizational psychology, the environmental psychology, and the applied social psychology thematic areas with a strong tendency towards the correlational quantitative paper type. On the other hand, the cognitive processes and the other basic processes thematic areas are strongly associated with the experimental analysis paper type. Finally, there is a markedly noticeable correspondence between the theoretical paper type and the theory and method reflections in social psychology thematic area, a finding that reminds us that correspondence analysis is based on a logic of proximity that does not necessarily imply that there is an unequivocal association for each of the correspondences because it only indicates general tendencies.

Institutional affiliation and paper type. The results of the correspondence analysis between paper type and institutional affiliation of the authors are laid out in Table 3 and Table 4 of Appendix B.

In this case, the distribution of institutional affiliation and paper type is clearly ordered along three axes with the following polarities: a) quantitative - qualitative: b) empirical - theoretical; and c) experimental - theoretical. On the one hand, Figure 4 (see also Figure 5 and Figure 6) shows the clear associations between the Universidad Complutense

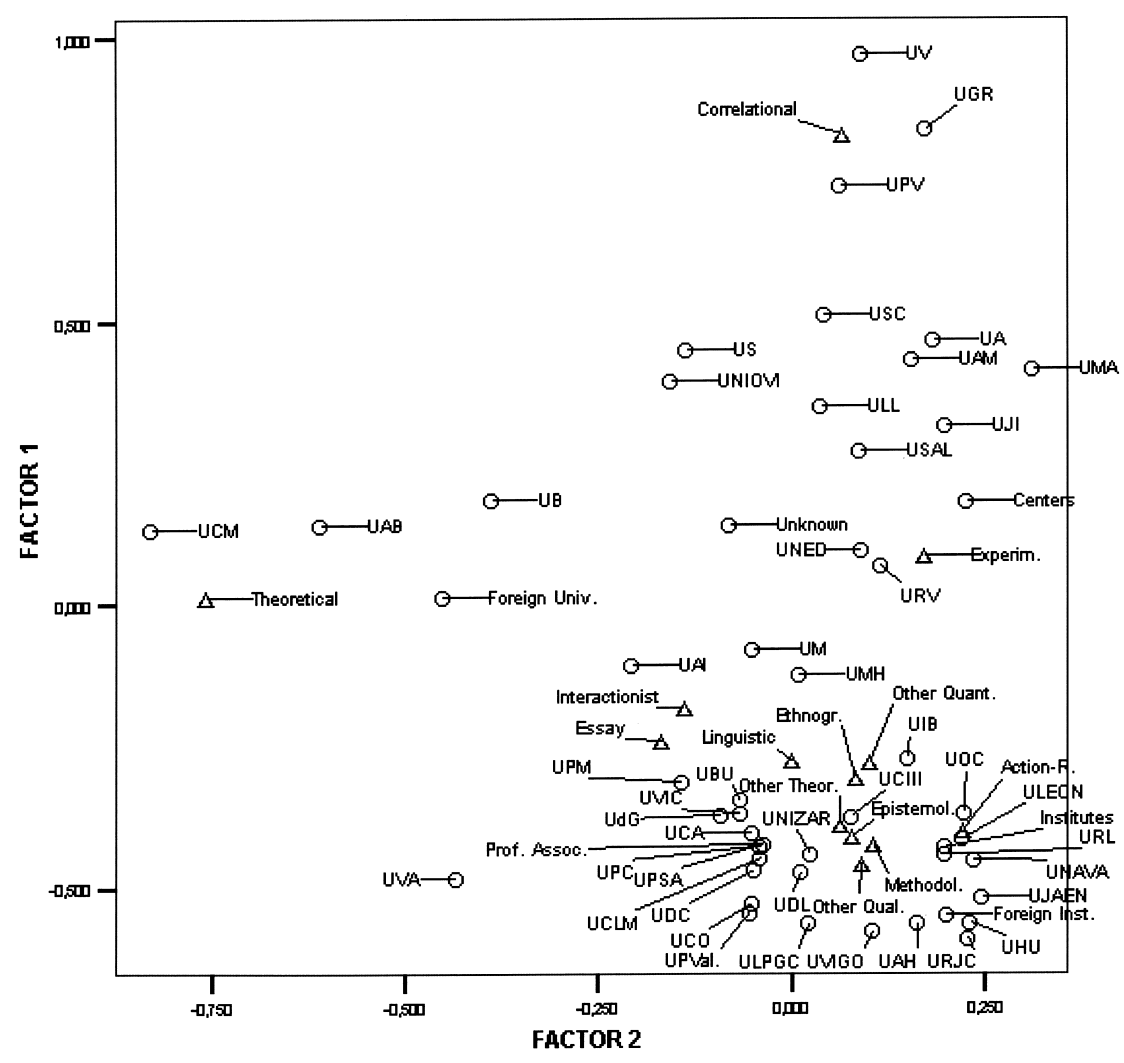

DIMENSIONS

Figure 4. Correspondence analysis: Institutional affiliation by paper type, factors 1 and 2. 


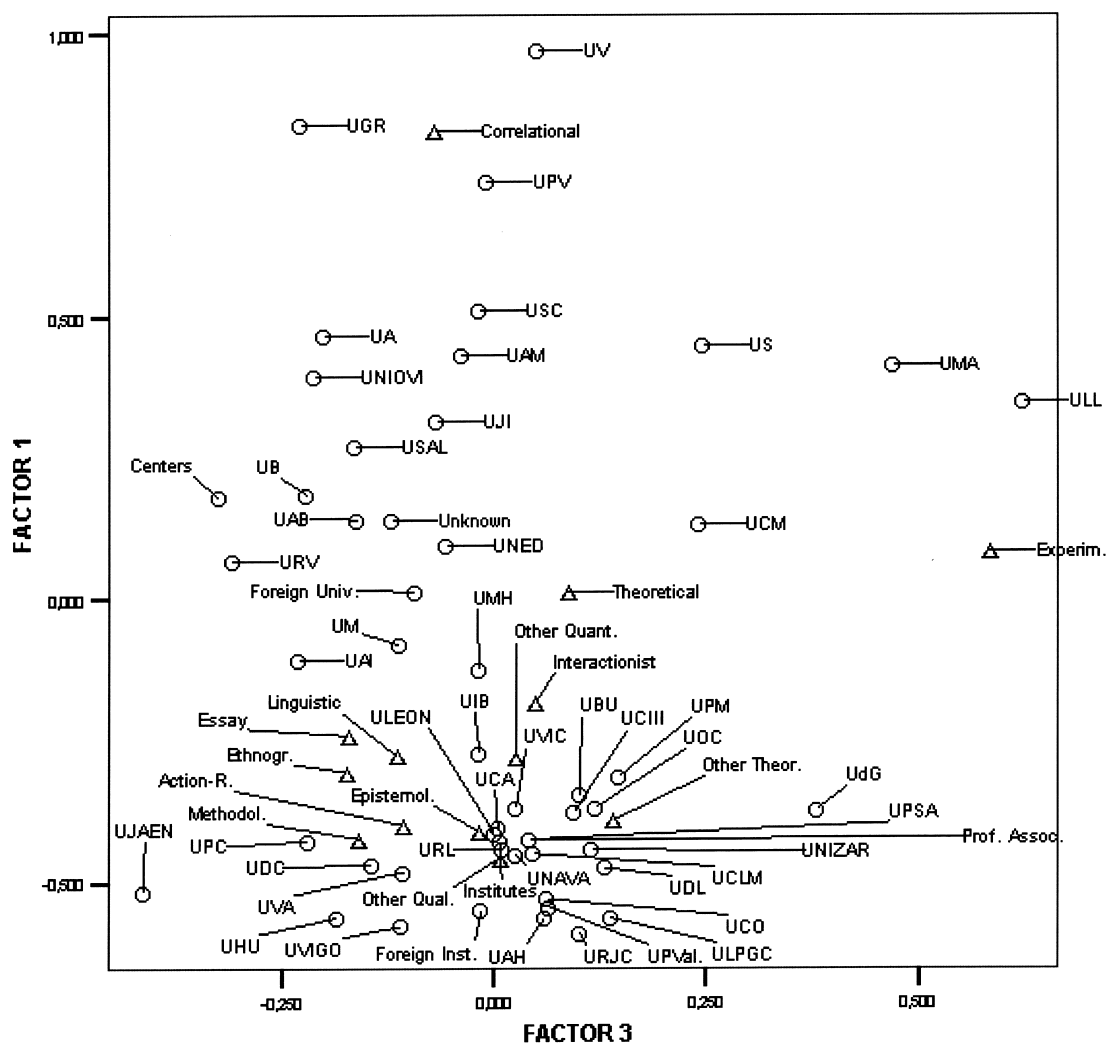

DIMENSIONS

O Institucional Affiliation

$\triangle$ Paper Type

Figure 5. Correspondence analysis: Institutional affiliation by paper type, factors 1 and 3 .

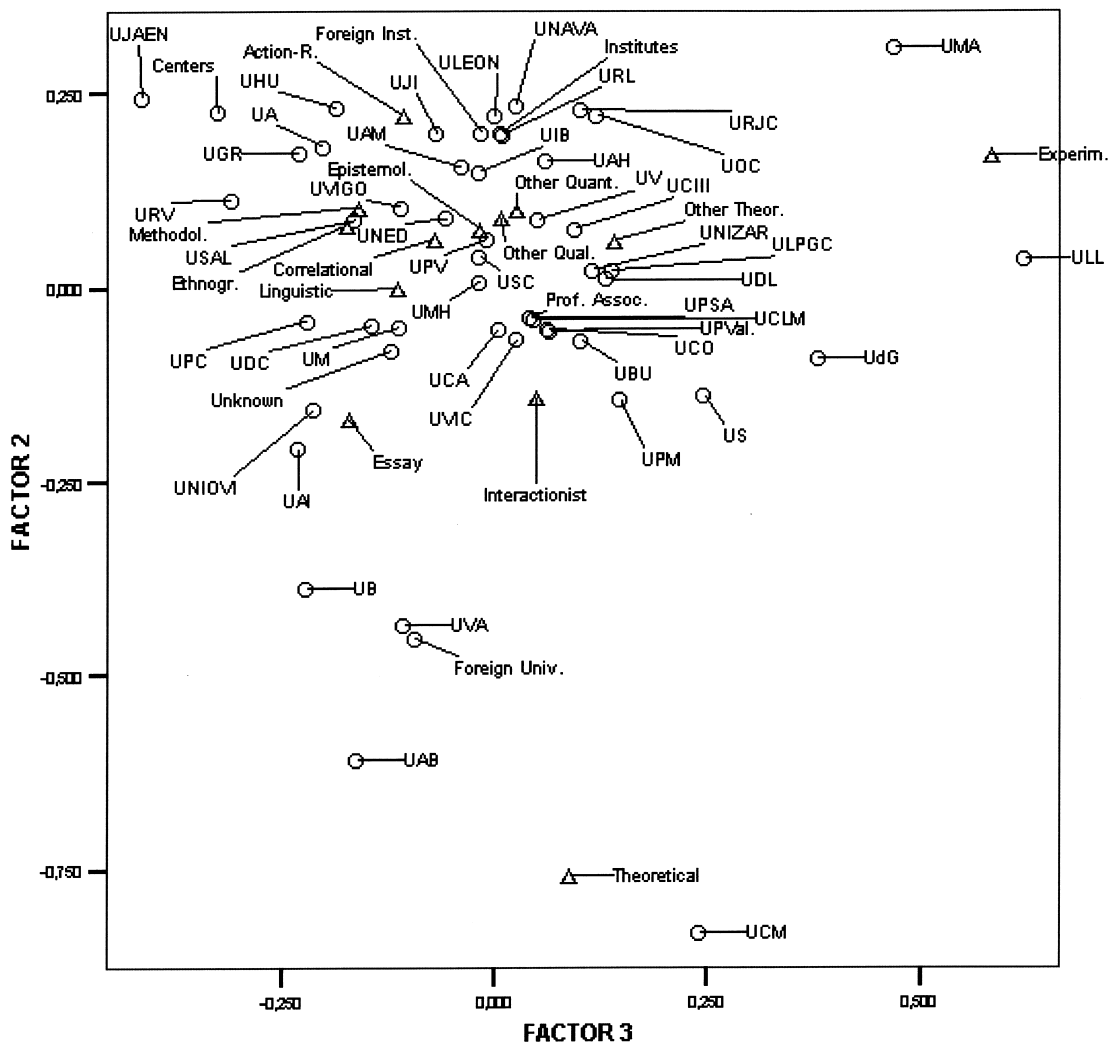

DIMENSIONS

O Institucional Affiliation

$\triangle$ Paper Type

Figure 6. Correspondence analysis: Institutional affiliation by paper type, factors 2 and 3. 
and the Universidad Autónoma de Barcelona with the theoretical paper type and the greater part of rest of the institutions with the empirical paper types. On the other, we can see the clear associations between the Universidad de Málaga, the UNED and the Universidad de La Laguna principally among the experimental quantitative paper type. The universities of Valencia, Granada, País Vasco, and Sevilla, among others, show a noticeably marked association among the correlational quantitative paper type.

Institutional affiliation and thematic area. In the correspondence analysis between institutional affiliation and thematic area there are three factors that show marked polarities: a) the first polarity separates applied social psychology from the basic processes area; $b$ ) the second polarity separates the work and organizational psychology and the applied social psychology areas from health psychology; and c) the third polarity separates applied social psychology from the work and organizational psychology ara. (Table 5 and Table 6 of Appendix B).

The results in Figure 7 (see also Figure 8 and Figure 9) shows that most of the institutions cannot distinguish from each other in terms of any thematic area and are related to a wide range of interests instead. Nevertheless, there are two clearly marked indicators of correspondence between institutional affiliation and thematic area. On the one hand there is the proximity of the Universidad de Valencia to the work and organizational psychology and the applied social psychology areas, and on the other there is the association of the Universidad de Sevilla and the Universidad de Alicante with the social psychology of health area. These results can hardly be a surprise to those who know well Spanish social psychology.

\section{Concluding Remarks}

The results of the descriptive analysis offer some interesting points to consider such as the growing trend towards co-authored papers, a fact that echoes similar studies in other disciplines such as Newman (2001), who found a mean of 3 authors per article. An impressive result this author found comes from the SPIRES database that shows a mean of 9 authors per article. This average may be attributed to the fact that high energy experimental physics

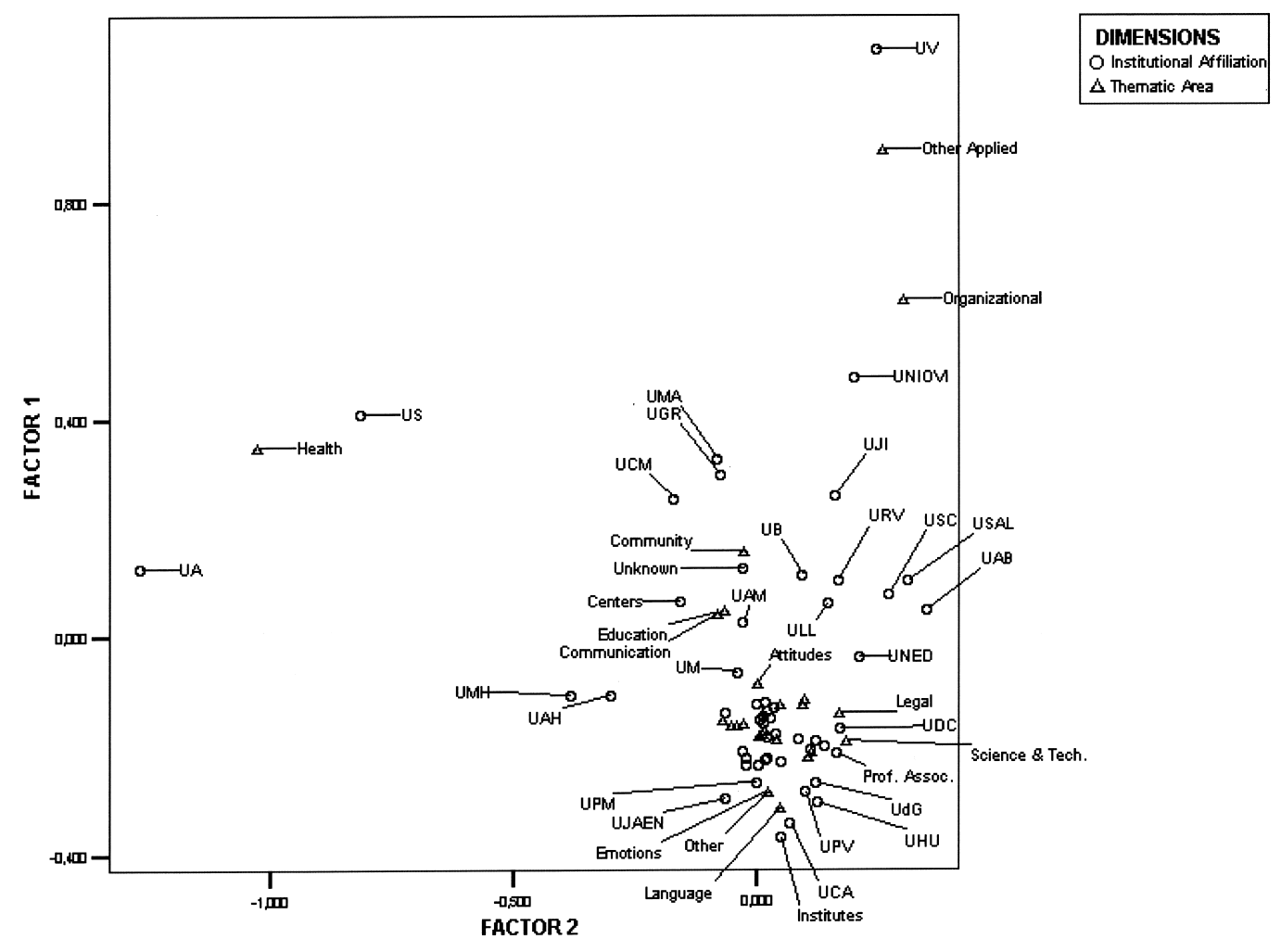

Figure 7. Correspondence analysis: Institutional affiliation by thematic area, factors 1 and $2 *$

* In order to offer a clear view of the correspondences, some labels are not shown.

For Institutional Affiliation, these labels are: Centers, Institutes, Prof. Assoc., UA, UAB, UAH, UAM, UB, UCA, UCM, UDC, UdG, UGR, UHU, UJAEN, UJI, ULL, UM, UMA, UMH, UNED, UNIOVI, Unknown, UPM, UPV, URV, US, USAL, USC, and UV for Institutional Affiliation.

For Thematic Area the labels not shown are: Attitudes, Communication, Community, Education, Emotions, Health, Language, Legal, Organizational, Other Applied, and Science \& Tech. 


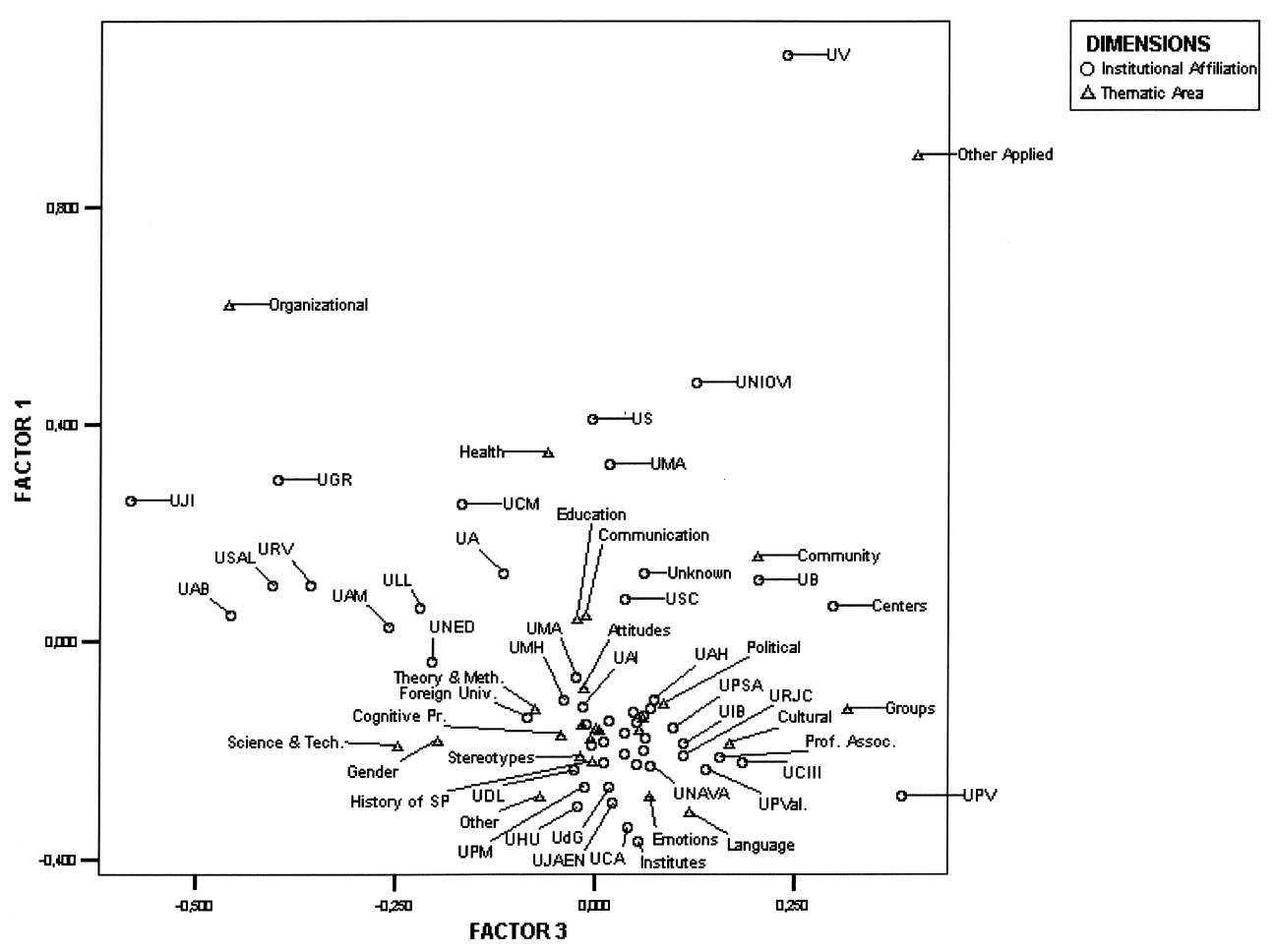

Figure 8. Correspondence analysis: Institutional affiliation by thematic area, factors 1 and $3^{*}$

* In order to offer a clear view of the correspondences, some labels are not shown. For Institutional Affiliation, these labels are: Foreign Inst., UBU, UCLM, UCO, UDC, ULEON, ULPGC, UNIZAR, UOC, UPC, URL, UVA, UVIC, and UVIGO. For Thematic Area the labels not shown are: Environmental, Identity, Influence, Legal, Other Basic Pr., and Pro-social Beh.

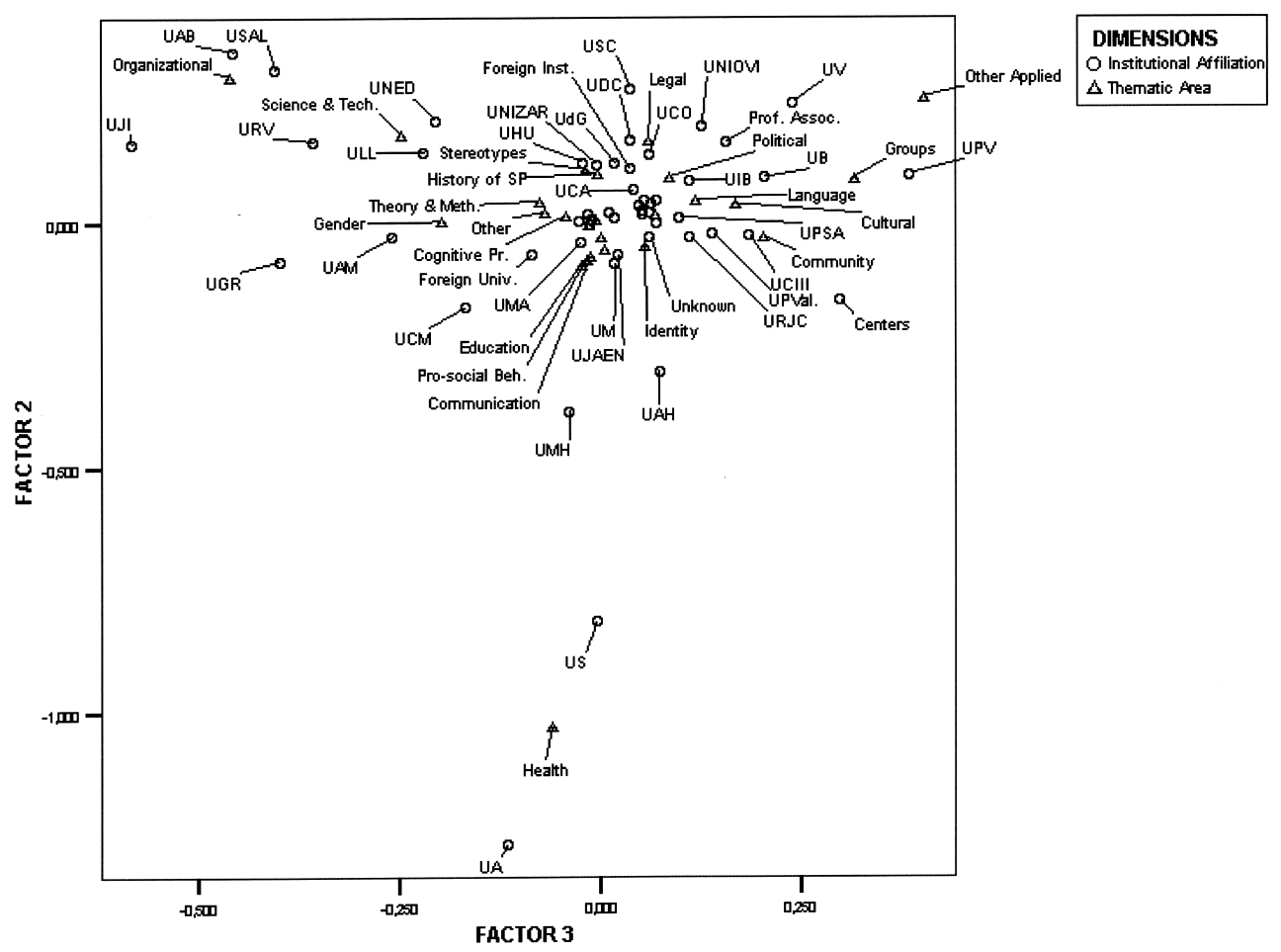

Figure 9. Correspondence analysis: Institutional affiliation by thematic area, factors 2 and $3 *$

* In order to offer a clear view of the correspondences, some labels are not shown. For Institutional Affiliation, these labels are: Institutes, UAI, UBU, UCLM, UDL, ULEON, ULPGC, UNAVA, UOC, UPC, UPM, URL, UVA, UVIC, and UVIGO. For Thematic Area the labels not shown are: Attitudes, Emotions, Environmental, Influence, and Other Basic Pr. 
research tends to consist of a large number of investigators, sometimes hundreds or thousands (there is one article signed by 1,682 authors). In the case of the conference papers in this study, many of them were probably been penned by more authors than the articles in the discipline's professional journals but data to prove this suspicion have not been considered here.

With regard to institutional affiliation, the greater presence of some universities and a slight but clearly observable decrease in their activity constitutes a significant finding. By the same token, there is a palpable increase in the number of institutions whose members are actively participating in conferences. This represents an increase in the discipline's scientific activity that is also attributable to author participation from foreign institutions.

The thematic areas in which the papers are grouped may be reflective of research interests favored by investigators but without forgetting the indirect influence of institutional policies and funding. In this sense, and in agreement with what Blanco and de la Corte (2001) have shown, it is clear that the applied social psychology thematic area predominates over the basic thematic area. However, the diversity of thematic areas in relationship to institutional affiliation, an exception made on areas such as work and organizational psychology, poses some important questions about the social conditions the affect the development of thematic areas. These questions may imply a deep review of dimensions and levels of analysis used when trying to understand the state and evolution of a discipline. The concentration of theoretical paper types in two institutions, as well as the emergence of the areas of cultural psychology and the social studies of science and technology thematic areas considering their links with critical perspectives is indicative of tendencies that require more attention. Indeed, future inquiries into the state of Spanish social psychology will need to take these trends into consideration.

Something similar is happening in relation to paper types. Although there are many empirical quantitative type papers, the growing tendency towards qualitative paper types supposes an unavoidable shift that needs to be considered within a much larger context. The growth in the number of specialized publications and of international meetings centered on qualitative research is evidence of the situation. This activity may be evidence of a network in movement based on the relationships established between researchers, orientations and schools, advancing a possible account of what Blanco and de la Corte (2001) describe with respect to the predominance of Anglo-Saxon models in psychosocial research.

And finally, conferences and meetings are a small but essential part of the scientific life of a discipline, and as such they need to be taken into account without losing sight of their connections with other dimensions of science. How do institutions value the participation of their members in conferences? What is the place of national conferences in relation to the process of publishing in international journals? What criteria are used in assessing submissions? Why are conferences not included in any index so their corresponding proceedings can be valued in terms of impact? There are many questions and all of them are worth being posed. That is why it is important to look at conferences despite the difficulties related to the lack of access to materials ${ }^{5}$ (Gallardo, 1996). Perhaps the social studies of science and technology is the area that should follow up on these observations. Studying the importance of the initial years of researchers' professional lives in terms of socialization and their contact with unknown subject areas may be a good place to start. In any case, we will still need to define the role scientific meetings play with regard to other spaces and forms of knowledge production and dissemination. As noted by Martens and Saretzki (1994), to talk about conferences is to talk about spaces. These are the very spaces in which we engage in conversations, where the core of the complex channels of the conceptual, methodological and empirical dissemination of our discipline is forged.

\section{References}

Agudelo, D., Bretón, J., Ortiz, G., Poveda, J., Teva, I., Valor, I., \& Vico, C. (2003). Análisis de la productividad científica de la psicología española a través de las tesis doctorales. Psicothema, 15, 595-609.

Blanco, A., \& de la Corte, L. (2001). The decade 1989-1998 in Spanish psychology: An analysis of research in Social Psychology. The Spanish Journal of Psychology, 4, 203-218.

Borgatti, S.P., Everett, M.G., \& Freeman, L.C. (2002). Ucinet for Windows: Software for Social Network Analysis. Harvard: Analytic Technologies.

Borgman, C.L. (Ed.). (1990). Scholarly communication and bibliometrics. Newbury Park, CA: Sage.

Borgman, C.L., \& Furner, J. (2002). Scholarly communication and bibliometrics. In B. Cronin (Ed.), Annual Review of Information Science and Technology, 36, 3-72.

Calatayud, C., Carpintero, H., Peiró, J.M., \& Tortosa, F.M. (1985). Estudio de la colaboración en el Psychological Review (18941945). Revista de Historia de la Psicología, 6, 161-184.

Callon, M., Courtial, J.P., \& Penan, H. (1993). La Scientometrie. París: PUF.

Carpintero, H. (1980). La psicología actual desde una perspectiva bibliométrica: una introducción. Análisis y Modificación de Conducta, 6, 9-23.

\footnotetext{
5 The difficulty of access to conference information is itself an area of inquiry that needs to be seriously considered.
} 
Carpintero, H., \& Peiró, J.M. (1978). Un método sociométrico de análisis de contenido: su aplicación a la investigación actual sobre 'generaciones'. Análisis y Modificación de la Conducta, $6,111-126$.

Carpintero, H., \& Peiró, J.M. (1980). Una perspectiva bibliométrica sobre la modificación de conducta. Revista de Historia de la Psicología, 1, 283-322.

Carpintero, H., \& Peiró, J.M. (Eds.). (1981). Psicologia contemporánea. Teoría y métodos cuantitativos para el estudio de su literatura científica. Valencia: Alfaplus.

Carpintero, H., Peiró, J.M., \& Quintanilla, I. (1977). El Anuario de Psicología (1969-1974). Un estudio estadístico y bibliométrico. Anuario de Psicología, 16, 23-34.

Gallardo, C. (1996). Estudio bibliométrico sobre la psicología en España. Papeles del Psicólogo, 64, 61-65.

García Santesmases, J. (1984). Análisis factorial de correspondencias. In J.J. Sánchez Carrión (Ed.), Introducción a las técnicas de análisis multivariable aplicadas a las ciencias sociales (pp. 75-105). Madrid: Centro de Investigaciones Sociológicas.

Ibáñez, T. (1990). Aproximaciones a la psicología social. Barcelona: Sendai.

Ikpaahindi, L. (1985). An overview of bibliometrics: Its measurements, laws, and their applications. Libri, 35, 163-176.

Íñiguez, L., Muñoz, J., Peñaranda, M.C., \& Martínez, L.M. (2006). La psicología social en España: estructuras de comunidades. REDES-Revista Hispana para el Análisis de Redes Sociales, 10(3). Retrieved February 4, 2007, from http://revistaredes.rediris.es/pdf-vol10/vol10_3.pdf

Leydesdorff, L. (2001). The challenge of scientometrics. Leiden: Universal.

Martens, B., \& Saretzki, T. (1994). Quantitative analysis of thematic structures in the field of biotechnology: A study on the basis of conference data. Scientometrics, 30, 117-128.

Miralles, J.L. (1980). Análisis bibliométrico de la producción científica en psicología. Perspectivas españolas. Análisis y Modificación de Conducta, 6, 65-75.
Moed, H., \& Visser, M. (2007). Developing bibliometric indicators of research performance in computer science: An exploratory study (No. CWTS Report 2007-01). Leiden: Centre for Science and Technology Studies (CWTS); Leiden University.

Molteni, V., \& Zulueta, M.A. (2002). Análisis de la visibilidad internacional de la producción científica argentina en las bases de datos Social Sciences Citation Index y Arts and Humanities Citation Index en la década de 1990-2000: estudio bibliométrico. Revista Española de Documentación Científica, 25, 455-465.

Newman, M.E.J. (2001). The structure of scientific collaboration networks. Proceedings of the National Academy of Sciences, 98, 404-409.

Pastor-Carballo, R., \& Carpintero, H. (1980). Análisis de la Revista de Psicología General y Aplicada (años 1946-1970). Revista de Historia de la Psicología, 1, 199-214.

Peiró, J.M. (1980). 'Colegios invisibles’en psicología. Análisis y Modificación de Conducta, 6, 25-50.

Peñaranda, M., Quiñones, E., \& López García, J.J. (2005). Veinte años de Anales de Psicología: una revista con raíces académicas (1984-2004). Anales de Psicología, 21, 181-198.

Pérez Alonso-Geta, P.M. (1985). La psicología en los congresos nacionales de pedagogía: una aproximación bibliométrica. Revista de Historia de la Psicología, 6, 145-160

Pritchard, A. (1969). Statiscal bibliography or bibliometrics. Journal of Documentation, 25, 348-369.

Rubio, M.C. (1998). Bibliometría y ciencias sociales. Clio, 7. Retrieved February 4, 2007, from http://clio.rediris.es/clionet/ articulos/bibliometria.htm

Tortosa, F. (1989). La psicología en España a través de algunas de sus revistas. Papeles del Psicólogo, 36-37, 79-82.

Tortosa, F., \& Carpintero, H. (1980). Evolución de la psicología en España en el siglo XX. Un estudio sobre manuales introductorios. Revista de Historia de la Psicología, 1, 353-391.

Received February, 18, 2007

Revision received, July, 1, 2007

Accepted November, 2, 2007 


\section{APPENDIX A}

Table 1 (Appendix A)

Paper Types

\begin{tabular}{|c|c|c|}
\hline Type & Sub-type & Definition \\
\hline \multirow[t]{5}{*}{ Theoretical } & Epistemological & An inquiry into epistemology \\
\hline & Theoretical & $\begin{array}{l}\text { A theoretical reflection paper on social psychological theory, a specific } \\
\text { model, or that describes a theory, microtheory or theoretical-conceptual } \\
\text { model }\end{array}$ \\
\hline & Theoretical-Methodological & $\begin{array}{l}\text { A theoretical reflection paper on methodological issues or theoretical- } \\
\text { methodological debates }\end{array}$ \\
\hline & Essay & $\begin{array}{l}\text { Any paper with another non empirical content such as a review, a } \\
\text { history, a disciplinary reflection, etc. }\end{array}$ \\
\hline & Theoretical (other) & A theoretical paper that does not fit the other definitions \\
\hline \multirow[t]{3}{*}{ Quantitative empirical } & Experimental quantitative & Any experimental based paper \\
\hline & Correlational quantitative & An empirical paper based on surveys and correlational techniques \\
\hline & Quantitative (other) & A quantitative empirical paper that does not fit the other definitions \\
\hline \multirow[t]{5}{*}{ Qualitative empirical } & Interactionist hermeneutic qualitative & $\begin{array}{l}\text { An interview based qualitative interactionist paper that uses content } \\
\text { analysis, grounded theory, or other interpretive means without using } \\
\text { linguistics }\end{array}$ \\
\hline & Linguistic qualitative & $\begin{array}{l}\text { An empirical paper that is based on any discourse analysis traditions } \\
\text { (cognitive, linguistic, psychosocial, critical or French school) }\end{array}$ \\
\hline & Ethnographic qualitative & A paper based on ethnography or participant observation \\
\hline & Action-Research qualitative & $\begin{array}{l}\text { A paper based on conventional or other action research participant } \\
\text { methods }\end{array}$ \\
\hline & Qualitative (other) & A qualitative paper that does not fit the other definitions \\
\hline
\end{tabular}


Table 2 (Appendix A)

Thematic Areas

Area Sub-area

\section{History of social psychology}

Theory and method in social psychology

Social studies of science and technology

Cultural psychology

Emotion

Cognitive processes and social thought

\section{Attitudes, beliefs and values}

Identity

Gender processes

Social influence processes

Stereotypes, prejudice and discrimination

Emotional bonds and pro-social and antisocial behavior

Collective and group processes

Social psychology of language

\section{Other basic psychosocial processes}

Work and organizational psychology

Social psychology of health

Community psychology

Environmental psychology

\section{Social psychology of education}

Legal psychology

Political psychology

Social psychology of communication

Applied social psychology - other specific areas
Epistemology, theories and models, methodological perspectives

Social psychology of science and knowledge, social psychology of technology

Cultural psychology, transcultural psychology (cross-cultural), transcultural social psychology (cross-cultural), psychology of the people

Social basis of emotion

Social cognition, social perception, social attribution, social explanations, social representations, discursive psychology

Self, social identity, social and cultural identity

Gender relations

Social influence

Intergroup prejudices and stereotypes, social discrimination, social marginalization* Interpersonal attraction, interpersonal relationships, helping behavior, altruism, aggression and aggressive behavior, violence

Social psychology of groups, social movements, collective and social memory

Social psychology of language

Work psychology, unemployment psychology, organizational psychology

Social psychology of health, substance abuse*, lifestyles*

Social service and community psychology, community psychology, quality of life*, social psychology of well-being, infancy and adolescence*, infancy and welfare*

Environmental psychology, quality of life*

Legal psychology

Political psychology

Communication, non-verbal communication, mass media communication

Social psychology of leisure and free time, social psychology of tourism, communication and marketing psychology, traffic psychology, geriatric psychology, program evaluation and design, consumer psychology, ergonomics, family and relationships, conflict and negotiation, violence, aggression and mistreatment, substances*, infancy and adolescence*, infancy and welfare*, immigration migration*, physical exercise and sports, lifestyles*, social marginalization*

\section{Others}

Note. *These sub-areas appear in more than one area. The grouping criteria depend on the paper's orientation or emphasis. 


\section{APPENDIX B}

Table 1 (Appendix B)

Correspondence Analysis Factors: Thematic Area by Paper Type

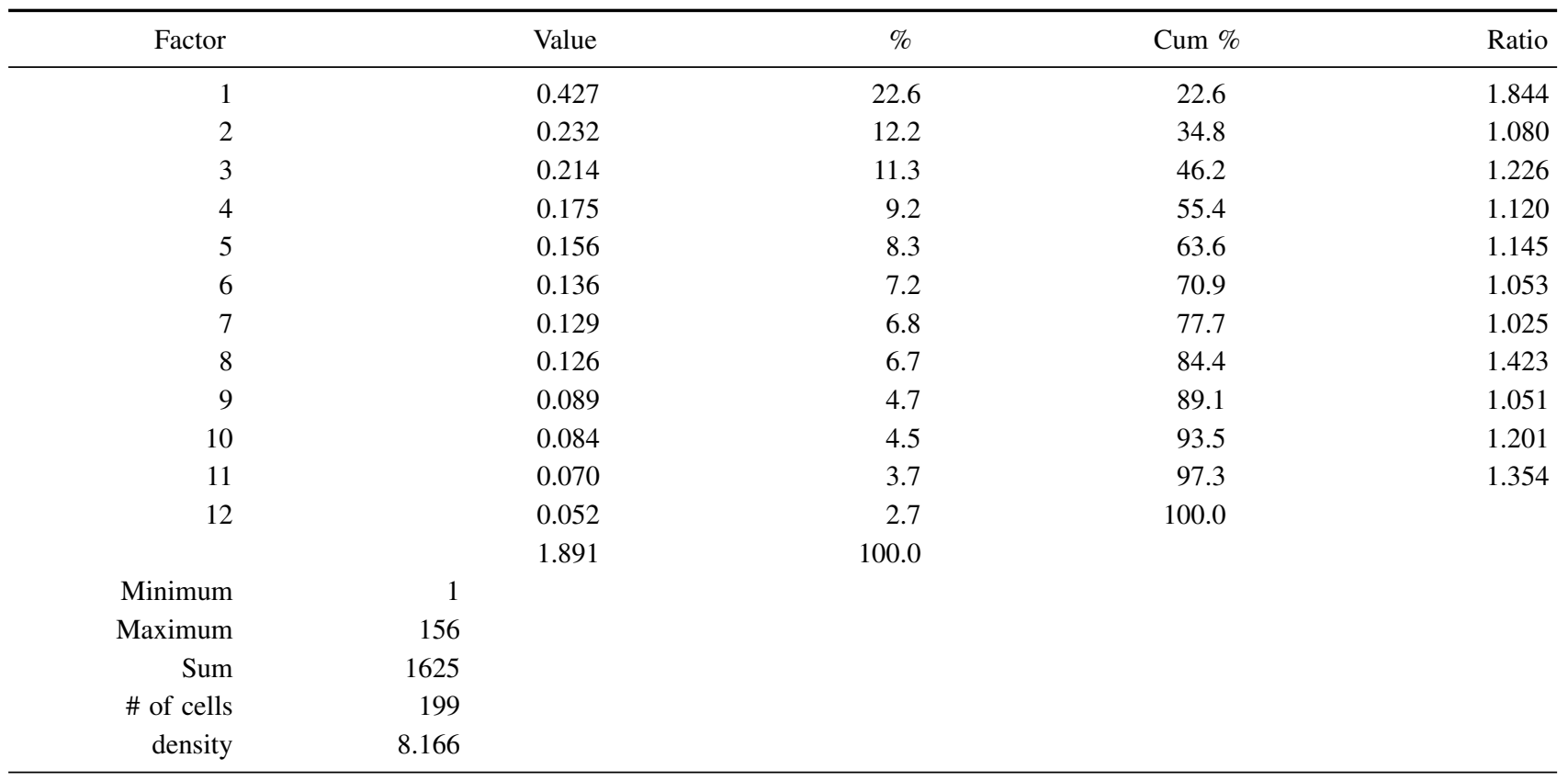


Table 2 (Appendix B)

Correspondence Analysis Coordinates: Thematic Area by Paper Type

\begin{tabular}{|c|c|c|c|c|c|}
\hline & Dimensions & Labels & 1 & 2 & 3 \\
\hline 1 & Attitudes, beliefs, and social values & Attitudes & 0.095 & 0.267 & 0.095 \\
\hline 2 & Emotions & Emotions & 0.355 & -0.120 & 0.355 \\
\hline 3 & Stereotypes, prejudices and social discrimination & Stereotypes & 0.143 & 0.028 & 0.143 \\
\hline 4 & Social studies of science and technology & Science \& Technology & 0.387 & -0.249 & 0.387 \\
\hline 5 & History of social psychology & History of Social Psychology & 0.614 & 0.179 & 0.614 \\
\hline 6 & Identity & Identity & -0.026 & 0.499 & -0.026 \\
\hline 7 & Other & Other & 0.607 & 0.134 & 0.607 \\
\hline 8 & Other basic psychosocial processes & Other Basic Processes & 0.539 & 0.006 & 0.539 \\
\hline 9 & Cognitive processes and social thought & Cognitive Processes & 0.428 & 0.207 & 0.428 \\
\hline 10 & Gender processes & Gender & 0.018 & 0.025 & 0.018 \\
\hline 11 & Social influence processes & Influence & 0.665 & -0.058 & 0.665 \\
\hline 12 & Group and collective processes & Groups & 0.183 & 0.002 & 0.183 \\
\hline 13 & Environmental psychology & Environmental & -0.247 & 0.081 & -0.247 \\
\hline 14 & Community psychology & Community & 0.062 & -0.280 & 0.062 \\
\hline 15 & Cultural psychology & Cultural & 0.165 & 0.193 & 0.165 \\
\hline 16 & Legal psychology & Legal & 0.309 & 0.097 & 0.309 \\
\hline 17 & Work and organizational psychology & Organizational & -0.731 & 0.003 & -0.731 \\
\hline 18 & Political psychology & Political & -0.036 & -0.231 & -0.036 \\
\hline 19 & Applied social psychology - other specific areas & Other Applied & -0.516 & -0.052 & -0.516 \\
\hline 20 & Social psychology of communication & Communication & 0.399 & 0.328 & 0.399 \\
\hline 21 & Social psychology of education & Education & -0.265 & -0.038 & -0.265 \\
\hline 22 & Social psychology of health & Health & -0.521 & 0.017 & -0.521 \\
\hline 23 & Social psychology of language & Language & 0.114 & 0.250 & 0.114 \\
\hline 24 & Affectional bonds and pro-social and anti-social behavior & Pro-social behavior & 0.182 & 0.109 & 0.182 \\
\hline 25 & Theory and method in social psychology & Theory \& method & 0.338 & -0.764 & 0.338 \\
\hline 1 & Epistemological & Epistemological & 0.355 & -0.196 & 0.355 \\
\hline 2 & Theoretical & Theoretical & -0.190 & -0.435 & -0.190 \\
\hline 3 & Theoretical-Methodological & Methodological & 0.269 & -0.205 & 0.269 \\
\hline 4 & Essay & Essay & 0.048 & -0.158 & 0.048 \\
\hline 5 & Theoretical (other) & Other Theories & 0.370 & 0.117 & 0.370 \\
\hline 6 & Experimental quantitative & Experimental & 0.313 & 0.011 & 0.313 \\
\hline 7 & Correlational quantitative & Correlational & -0.630 & 0.107 & -0.630 \\
\hline 8 & Quantitative (other) & Other Quantitative & 0.278 & -0.225 & 0.278 \\
\hline 9 & Interactionist hermeneutic qualitative & Interactionist & 0.401 & 0.084 & 0.401 \\
\hline 10 & Linguistic qualitative & Linguistic & 0.332 & 0.002 & 0.332 \\
\hline 11 & Ethnographic qualitative & Ethnographic & 0.369 & 0.37 & 0.369 \\
\hline 12 & Action-Research qualitative & Action-Research & 0.410 & 0.049 & 0.410 \\
\hline 13 & Qualitative (other) & Other Qualitative & 0.331 & 0.537 & 0.331 \\
\hline
\end{tabular}


Table 3 (Appendix B)

Correspondence Analysis Factors: Institutional Affiliation by Paper Type

\begin{tabular}{|c|c|c|c|c|}
\hline Factor & Value & $\%$ & Cum $\%$ & Ratio \\
\hline 1 & 0.488 & 26.4 & 26.4 & 2.134 \\
\hline 2 & 0.229 & 12.4 & 38.8 & 1.230 \\
\hline 3 & 0.186 & 10.1 & 48.9 & 1.133 \\
\hline 4 & 0.164 & 8.9 & 57.7 & 1.030 \\
\hline 5 & 0.159 & 8.6 & 66.4 & 1.313 \\
\hline 6 & 0.121 & 6.6 & 72.9 & 1.080 \\
\hline 7 & 0.112 & 6.1 & 79.0 & 1.114 \\
\hline 8 & 0.101 & 5.5 & 84.5 & 1.149 \\
\hline 9 & 0.088 & 4.7 & 89.2 & 1.114 \\
\hline 10 & 0.079 & 4.3 & 93.5 & 1.135 \\
\hline 11 & 0.069 & 3.8 & 97.2 & 1.355 \\
\hline \multirow[t]{2}{*}{12} & 0.051 & 2.8 & 100.0 & \\
\hline & 1.849 & 100.0 & & \\
\hline Minimum & 1 & & & \\
\hline Maximum & 388 & & & \\
\hline Sum & 3764 & & & \\
\hline \# of cells & 283 & & & \\
\hline density & 13.3 & & & \\
\hline
\end{tabular}


Table 4 (Appendix B)

Correspondence Analysis Coordinates: Institutional Affiliation by Paper Type

\begin{tabular}{|c|c|c|c|c|c|}
\hline & Dimensions & Labels & 1 & 2 & 3 \\
\hline 1 & Centers & Centers & 0.181 & 0.226 & -0.325 \\
\hline 2 & Spanish institutes & Institutes & -0.429 & 0.199 & 0.007 \\
\hline 3 & Professional associations & Prof. Associations & -0.424 & -0.036 & 0.042 \\
\hline 4 & Foreign universities & Foreign Universities & 0.014 & -0.452 & -0.094 \\
\hline 5 & Foreign institutes & Foreign Institutes & -0.549 & 0.200 & -0.015 \\
\hline 6 & Unknown & Unknown & 0.140 & -0.080 & -0.121 \\
\hline 7 & Centers & UNED & 0.095 & 0.090 & -0.056 \\
\hline 8 & Universidad Autónoma de Barcelona & UAB & 0.142 & -0.609 & -0.161 \\
\hline 9 & Universidad Autónoma de Madrid & UAM & 0.432 & 0.156 & -0.039 \\
\hline 10 & Universidad Carlos III de Madrid & UCIII & -0.375 & 0.077 & 0.095 \\
\hline 11 & Universidad Complutense & UCM & 0.133 & -0.829 & 0.242 \\
\hline 12 & Universidad de Alcalá de Henares & $\mathrm{UAH}$ & -0.562 & 0.164 & 0.060 \\
\hline 13 & Universidad de Alicante & UA & 0.467 & 0.183 & -0.201 \\
\hline 14 & Universidad de Almería & UAl & -0.108 & -0.207 & -0.231 \\
\hline 15 & Universidad de Barcelona & UB & 0.187 & -0.388 & -0.221 \\
\hline 16 & Universidad de Burgos & UBU & -0.346 & -0.067 & 0.102 \\
\hline 17 & Universidad de Cádiz & UCA & -0.405 & -0.052 & 0.005 \\
\hline 18 & Universidad de Castilla - La Mancha & UCLM & -0.449 & -0.040 & 0.047 \\
\hline 19 & Universidad de Córdoba & UCO & -0.529 & -0.052 & 0.063 \\
\hline 20 & Universidad de Girona & UdG & -0.372 & -0.091 & 0.38 \\
\hline 21 & Universidad de Granada & UGR & 0.840 & 0.174 & -0.228 \\
\hline 22 & Universidad de Huelva & UHU & -0.562 & 0.232 & -0.185 \\
\hline 23 & Universidad de Jaén & UJAEN & -0.517 & 0.246 & -0.414 \\
\hline 24 & Universidad de La Coruña & UDC & -0.469 & -0.048 & -0.144 \\
\hline 25 & Universidad de La Laguna & ULL & 0.350 & 0.038 & 0.623 \\
\hline 26 & Universidad de las Islas Baleares & UIB & -0.271 & 0.150 & -0.017 \\
\hline 27 & Universidad de Las Palmas de Gran Canaria & ULPGC & -0.562 & 0.023 & 0.137 \\
\hline 28 & Universidad de León & ULEON & -0.415 & 0.221 & 0.001 \\
\hline 29 & Universidad de Lleida & UDL & -0.474 & 0.012 & 0.131 \\
\hline 30 & Universidad de Málaga & UMA & 0.416 & 0.311 & 0.471 \\
\hline 31 & Universidad de Murcia & UMA & -0.080 & -0.050 & -0.112 \\
\hline 32 & Universidad de Oviedo & UNIOVI & 0.396 & -0.156 & -0.212 \\
\hline 33 & Universidad de Salamanca & USAL & 0.272 & 0.088 & -0.163 \\
\hline 34 & Universidad de Santiago & USC & 0.513 & 0.041 & -0.017 \\
\hline 35 & Universidad de Sevilla & US & 0.451 & -0.137 & 0.246 \\
\hline 36 & Universidad de Valencia & UV & 0.972 & 0.089 & 0.051 \\
\hline 37 & Universidad de Valladolid & UVA & -0.481 & -0.434 & -0.106 \\
\hline 38 & Universidad de Vic & UVIC & -0.369 & -0.066 & 0.026 \\
\hline 39 & Universidad de Vigo & UVIGO & -0.577 & 0.105 & -0.11 \\
\hline 40 & Universidad de Zaragoza & UNIZAR & -0.442 & 0.024 & 0.115 \\
\hline 41 & Universidad del País Vasco & UPV & 0.741 & 0.063 & -0.009 \\
\hline 42 & Universidad Jaume I & UJI & 0.316 & 0.199 & -0.067 \\
\hline 43 & Universidad Miguel Hernández & UMH & -0.123 & 0.009 & -0.017 \\
\hline 44 & Universidad Oberta de Catalunya & UOC & -0.368 & 0.223 & 0.120 \\
\hline 45 & Universidad Politécnica de Catalunya & UPC & -0.427 & -0.041 & -0.220 \\
\hline 46 & Universidad Politécnica de Madrid & UPM & -0.314 & -0.142 & 0.147 \\
\hline 47 & Universidad Politécnica de Valencia & UPVal. & -0.543 & -0.054 & 0.066 \\
\hline 48 & Universidad Pontificia de Salamanca & UPSA & -0.424 & -0.036 & 0.042 \\
\hline 49 & Universidad Pública de Navarra & UNAVA & -0.451 & 0.235 & 0.025 \\
\hline 50 & Universidad Ramón Llull & URL & -0.443 & 0.198 & 0.010 \\
\hline 51 & Universidad Rey Juan Carlos I & URJC & -0.588 & 0.229 & 0.102 \\
\hline 52 & Universidad Rovira i Virgili & URV & 0.070 & 0.114 & -0.309 \\
\hline 1 & Epistemological & Epistemological & -0.411 & 0.077 & -0.017 \\
\hline 2 & Theoretical & Theoretical & 0.015 & -0.757 & 0.087 \\
\hline 3 & Theoretical-Methodological & Methodological & -0.423 & 0.105 & -0.159 \\
\hline 4 & Essay & Essay & -0.241 & -0.168 & -0.172 \\
\hline 5 & Theoretical (other) & Other Theoretical & -0.390 & 0.062 & 0.141 \\
\hline 6 & Experimental quantitative & Experimental & 0.087 & 0.171 & 0.584 \\
\hline 7 & Correlational quantitative & Correlational & 0.830 & 0.064 & -0.070 \\
\hline 8 & Quantitative (other) & Other Quantitative & -0.279 & 0.101 & 0.027 \\
\hline 9 & Interactionist hermeneutic qualitative & Interactionist & -0.183 & -0.140 & 0.049 \\
\hline 10 & Linguistic qualitative & Linguistic & -0.277 & 0.000 & -0.114 \\
\hline 11 & Ethnographic qualitative & Ethnographic & -0.306 & 0.082 & -0.173 \\
\hline 12 & Action-Research qualitative & Action-Research & -0.399 & 0.222 & -0.107 \\
\hline 13 & Qualitative (other) & Other Qualitative & -0.457 & 0.091 & 0.007 \\
\hline
\end{tabular}


Table 5 (Appendix B)

Correspondence Analysis Factors: Institutional Affiliation by Thematic Area

\begin{tabular}{|c|c|c|c|c|}
\hline Factor & Value & $\%$ & Cum \% & Ratio \\
\hline 1 & 0.329 & 14.1 & 14.1 & 1.186 \\
\hline 2 & 0.278 & 11.9 & 26.1 & 1.453 \\
\hline 3 & 0.191 & 8.2 & 34.3 & 1.089 \\
\hline 4 & 0.175 & 7.5 & 41.8 & 1.056 \\
\hline 5 & 0.166 & 7.1 & 48.9 & 1.282 \\
\hline 6 & 0.130 & 5.6 & 54.5 & 1.013 \\
\hline 7 & 0.128 & 5.5 & 60.0 & 1.105 \\
\hline 8 & 0.116 & 5.0 & 65.0 & 1.149 \\
\hline 9 & 0.101 & 4.3 & 69.3 & 1.161 \\
\hline 10 & 0.087 & 3.7 & 73.0 & 1.088 \\
\hline 11 & 0.080 & 3.4 & 76.4 & 1.133 \\
\hline 12 & 0.070 & 3.0 & 79.5 & 1.106 \\
\hline 13 & 0.064 & 2.7 & 82.2 & 1.049 \\
\hline 14 & 0.061 & 2.6 & 84.8 & 1.086 \\
\hline 15 & 0.056 & 2.4 & 87.2 & 1.011 \\
\hline 16 & 0.055 & 2.4 & 89.5 & 1.183 \\
\hline 17 & 0.047 & 2.0 & 91.5 & 1.185 \\
\hline 18 & 0.039 & 1.7 & 93.2 & 1.175 \\
\hline 19 & 0.033 & 1.4 & 94.7 & 1.090 \\
\hline 20 & 0.031 & 1.3 & 96.0 & 1.112 \\
\hline 21 & 0.028 & 1.2 & 97.2 & 1.141 \\
\hline 22 & 0.024 & 1.0 & 98.2 & 1.043 \\
\hline 23 & 0.023 & 1.0 & 99.2 & 1.272 \\
\hline \multirow[t]{2}{*}{24} & 0.018 & 0.8 & 100.0 & \\
\hline & 2.329 & 100.0 & & \\
\hline Minimum & 1 & & & \\
\hline Maximum & 186 & & & \\
\hline Sum & 3764 & & & \\
\hline \# of cells & 405 & & & \\
\hline density & 9.294 & & & \\
\hline
\end{tabular}

